\title{
ANALYSIS OF INTERBODY VERSUS POSTEROLATERAL FUSION FOR LUMBAR SPONDYLOSIS
}

\author{
ANÁLISE DA ARTRODESE VERTEBRAL INTERSOMÁTICA VERSUS POSTEROLATERAL \\ NA ESPONDILOSE LOMBAR
}

\author{
ANÁLISIS DE LA FUSIÓN INTERSOMÁTICA VERSUS POSTEROLATERAL \\ EN LA ESPONDILOSIS LUMBAR
}

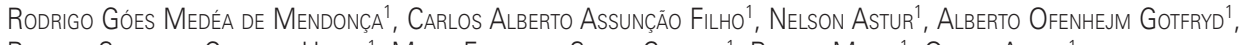

Ricardo Shigueaki Galhego Umeta', Maria Fernanda Silber Caffaro ${ }^{1}$, Robert Meves ${ }^{1}$, Osmar Avanzi ${ }^{1}$

\begin{abstract}
Objective: To evaluate and compare radiographic and clinical evaluation of patients undergoing interbody fusion versus posterolateral fusion of the lumbar spine. Methods: Retrospective study of patients diagnosed with lumbar spondylosis that were surgically treated in the period from 2012 to 2014. The results were observed by clinical evaluation by the Visual Analogue Scale (VAS) for low back and leg pain. We evaluated functional results and quality of life through the application of the Oswestry Disability Index (ODI) and the Short Form-36 (SF-36) questionnaires, respectively. The pre and postoperative condition were compared in Group 1 (interbody fusion) and Group 2 (posterolateral fusion), in addition to evaluation of fusion by means of post-operative radiograph. Results: A total of 30 patients of 36 were eligible, 12 in Group 1 and 18 in Group 2. The mean follow-up was 10.1 months. Statistical analysis showed similar scores for back and leg pain VAS, SF-36 function scores and Oswestry between groups with interbody and posterolateral fusion, and compared within these groups regarding the pre- and postoperative condition, and found no statistical significance. The successful fusion was similar in both groups, with 11 of 12 patients in Group 1 showing bone fusion and 17 of 18 in Group 2 showing arthrodesis. Conclusion: No clinical or radiographic differences between patients who underwent posterolateral or interbody fusion were observed. Both methods showed improvement in functional outcome and pain reduction.
\end{abstract}

Keywords: Spinal fusion; Treatment outcome; Spondylosis; Lumbar vertebrae.

\section{RESUMO}

Objetivo: Avaliar e comparar a evolução radiográfica e clínica dos pacientes submetidos à artrodese intersomática em comparação com a posterolateral na coluna lombar. Métodos: Estudo retrospectivo de pacientes com diagnóstico de espondilose lombar, submetidos ao tratamento cirúrgico no período de 2012 a 2014. Os resultados foram observados por avaliação clínica pela aplicação da Escala Visual Analógica (EVA) para dor com relação à dor lombar e nos membros inferiores. Foram avaliados resultados funcionais e de qualidade de vida através dos questionários Oswestry Disability Index (ODI) e o Short Form-36 (SF-36), respectivamente. A situação pré e pós-operatória foi comparada no Grupo 1 (artrodese intersomática) e no Grupo 2 (artrodese posterolateral), além da avaliação da fusão por meio de radiografia pós-operatória. Resultados: Foram avaliados 30 pacientes de 36 elegíveis, sendo 12 do Grupo 1 e 18 do Grupo 2. 0 seguimento médio dos pacientes foi de 10,1 meses. Os resultados da análise estatística mostraram pontuações semelhantes para EVA lombar, EVA na perna, função no SF-36 e Oswestry entre os grupos com artrodese intersomática e posterolateral, assim como na comparação dentro desses grupos referente ao estado pré e pós-operatório, sem significância estatística. A fusão bem-sucedida foi semelhante nos grupos, com 11 de 12 no Grupo 1 mostrando sucesso e 17 de 18 no Grupo 2 também evidenciando artrodese. Conclusão: Não foram observadas diferenças clínicas ou radiográficas entre pacientes submetidos à artrodese intersomática e posterolateral. Ambos os métodos apresentaram melhora no resultado funcional e na redução da dor.

Descritores: Fusão vertebral; Resultado do tratamento; Espondilose; Vértebras lombares.

\section{RESUMEN}

Objetivo: Examinar y comparar la evaluación radiográfica y clínica de los pacientes sometidos a la fusión intersomática frente a la fusión posterolateral de la columna lumbar. Métodos: Estudio retrospectivo de los pacientes diagnosticados con espondilosis lumbar que fueron tratados quirúrgicamente en el período desde 2012 hasta 2014. Se observaron los resultados de la evaluación clínica por la Escala Visual Análoga (EVA) para el dolor en relación con el dolor de lumbar y de los miembros inferiores. Evaluamos el resultado funcional y la calidad de vida por medio de los cuestionarios Índice Discapacidad de Oswestry (ODI) y el Short Form-36 (SF-36), respectivamente. Antes y después de la intervención se compararon el Grupo 1 (fusión intersomática) y Grupo 2 (artrodesis posterolateral), además de la evaluación de la fusión a través de la radiografía postoperatoria. Resultados: Un total de 30 pacientes de 36 elegibles, 12 en el Grupo 1 y 18 en el Grupo 2. El seguimiento medio de los pacientes fue de 10,1 meses. Los resultados del análisis estadístico mostraron puntuaciones similares para EVA lumbar, EVA de las extremidades inferiores, SF-36 y Oswestry entre los grupos con artrodesis intersomática y artrodesis posterolateral, asi como la comparación dentro de estos grupos en relación con el estado de pre y postoperatorio y sin significación estadística. La fusión fue similar en ambos grupos con 11 de 12 en el Grupo 1 que tuvieron éxito y 17 de 18 en el Grupo 2 que presentaron artrodesis. Conclusión: No se observaron diferencias clínicas o radiográficas entre los pacientes sometidos a artrodesis intersomática y posterolateral. Ambos métodos mostraron una mejoría en los resultados funcionales y la reducción del dolor.

Descriptores: Fusión vertebral; Resultado del tratamiento; Espondilosis; Vértebras lumbares.

1. Faculdade de Ciências Médicas da Santa Casa de São Paulo - Pavilhão “Fernandinho Simonsen", Department of Orthopedics andTraumatology, Spine Group, São Paulo, SP, Brazil.

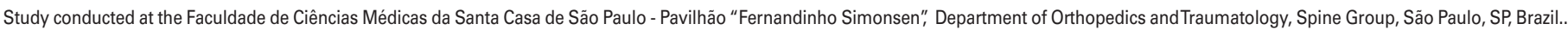
Correspondence: Rua Dr. Cesário Motta Jr, 112. São Paulo, SP, BraZil. 01227-900. dot.coluna@ santacasasp.org.br 


\section{INTRODUCTION}

Spondylosis, or degenerative disease of the lumbar spine, is quite prevalent in the general population and remains one of the main causes of inability to work. It is estimated that $53 \%$ of economically active Brazilians will suffer from lower back pain during their lives, and $33 \%$ will have associated sciatic pain. ${ }^{1}$ Lower back pain, sciatica, numbness, weakness in the legs and intermittent claudication are the main symptoms caused by degeneration of the lumbar spine. These symptoms are directly linked to the degree of degeneration, spondylosis, instability, and stenosis of the lumbar vertebral canal. When conservative treatment fails, surgery is considered and in many cases stabilization through arthrodesis of the lower spine is required in addition to decompression. Currently, there is a series of fusion techniques available, and these are indicated according to the patient, the hospital availability, and the surgeon's preference. ${ }^{4}$

Although surgical treatment for spondylosis via lumbar vertebral fusion has been evaluated and proven effective by various randomized controlled studies (RCSs), there is still controversy around patient selection and the choice of the surgical technique for the fusion. ${ }^{5}$ Prior studies have reported the advantages, technical difficulties, clinical results, and postoperative complications of 360 degree arthrodesis, i.e., circumferential with the use of an interbody spacer (cage) and posterior access posterolateral fusion. However, surgeons still have differing opinions as to the real impacts on the patient's quality of life, and there is no gold standard method for arthrodesis of degenerative disease in the lumbar spine. ${ }^{6}$

The objective of this study was to evaluate and compare the radiographical and clinical evolution of patients submitted to interbody arthrodesis (cage) versus posterolateral fusion of the lumbar spine for degenerative lumbar disease.

\section{CASE SERIES AND METHODS}

Following approval by the Institutional Review Board (CAAE:16435713.6.0000.5479), a retrospective, cross-sectional evaluation was conducted. Patients were selected who met the inclusion criteria of complete clinical and radiographic follow-up for a minimum of six months, and the patients were discriminated by sex, average age at surgery, and age range and extremes.

Patients who did not wish to participate in the study, those with diagnoses other than lumbar spondylosis, such as fractures or tumors, and patients with no confirmed diagnosis (incomplete medical records or lost imaging exams) were excluded from the study.

A total of 36 patients diagnosed with lumbar spondylosis and indicated for surgical treatment underwent decompression and lumbar arthrodesis using the TLIF (transforaminal interbody fusion) technique via the open or minimally invasive approach, depending on availability at the time of the procedure, in the Spine Surgery Group of our service during the period from September 2012 to January 2014. The surgical indication for lumbar spondylosis was defined as the failure of clinical treatment after more than six weeks of physical therapy, with radiographic alterations due to isthmic and degenerative spondylosis, central or foraminal stenosis, or lumbar disc herniation, all associated with documented segmental instability requiring decompression and instrumented lumbar arthrodesis.

Following selection of the potential subjects, they were asked to appear for a clinical and functional reassessment. The medical files of each subject included a prior preoperative assessment performed using the visual analog scale (VAS), the Short Form-36 (SF-36) quality of life questionnaire, and the Oswestry Disability Index (ODI) for dysfunction, as per the Group's routine registration procedure for surgical patients. Of the 36 patients selected, five chose not to participate in the study and one died, giving a final number of 30 subjects, all of whom signed the informed consent form.

The patients were stratified based on the lumbar fusion surgical technique to which they had been submitted: Group 1 - interbody (cage) arthrodesis with 12 patients, 2 male and 10 female, with an average age of 43.67 years (ranging from 31 to 55 years of age);
Group 2- posterolateral arthrodesis with 18 patients, 7 males and 11 females with an average age of 57.44 (ranging from 44 to 81 years of age). Both groups received local autologous bone grafts associated with iliac fragments where necessary.

The patients were reevaluated cross-sectionally for quality of life, intensity of pain, and personal satisfaction using questionnaires provided by the author, the Oswestry Disability Index Score (ODI), the Visual Analog Scale for Pain (VAS Pain), ${ }^{7}$ and the Short Form 36 (SF-36). ${ }^{8}$ Bone consolidation was also verified in anteroposterior and profile views of radiographs taken of the lumbar spine at the last outpatient visit, using the criteria of Linovitz. ${ }^{9}$ This is divided into four grades (grade 0 - no fusion, grade 1 - minimal fusion, grade 2 - moderate fusion, grade 3 - solid fusion) and considers grades 0 and 1 as failures and grades 2 and 3 as successes. General information was gathered, including surgery time, whether a blood transfusion was required, Body Mass Index (BMI), smoking, the need for reoperation, and any complications.

The chi-square or Fisher's exact tests were used to evaluate correlations between qualitative variables. The Kruskall-Wallis test was used to analyze the pre- and postoperative variables. SPSS for Windows (v. 17) software was used, and the results were considered statistically significant when $\mathrm{p}<0.05$.

\section{RESULTS}

At the end of follow-up the patients in both groups showed an improvement in their VAS and ODI scores as compared to the preoperative values.

The average surgical time was 275 minutes for Group 1 and 256 minutes for Group 2. The average final follow-up for all individuals was 10.1 months with a follow-up rate of $83.33 \%$ after subtracting losses. The average number of days of hospitalization was 3.66 days in Group 1 and 4.28 days in Group 2. There were no reoperations in Group 1, although there was one case of radiculopathy which improved with rehabilitation, one synthesis failure, but with consolidation achieved after six months, and two cage migrations that improved clinically after the patients refused to undergo additional procedures. In Group 2, two reoperations were required, one decompression for radiculopathy and one effective surgical cleaning due to a deep infection in a patient with rheumatoid arthritis under corticosteroid therapy, and finally, two cases who developed degenerative disease of the adjacent level and showed clinical improvement during outpatient follow-up.

The average number of fused levels was $1.3 \pm 0.9$ in Group 1 (range from 1 to 3 ) and $1.3 \pm 0.6$ in Group 2 (range from 1 to 2). The review of the pre-anesthesia patient assessments showed ASA (American Society of Anesthesiologists) ratings as follows: Group 1 - class 1 - 6 patients, class 2 - 6 patients; and Group 2 class $1-6$ patients, class $2-11$ patients, and class $3-1$ patient.

The distribution of the variables of the groups by category can be observed in Table 1. There were no statistically significant differences.

Group 1: The average VAS scores for lower back and legs were 7.39 and 7.19 , respectively, before surgery and 4.47 and 3.76 at the end of follow-up, showing improvements of $42.22 \%$ and $47.70 \%$ in the lower back and leg pain scales, respectively. The average ODI score was $58.49 \%$ before surgery and $31.30 \%$ at the end of follow-up, for an improvement of $46.49 \%$.

Group 2: The average VAS scores for lower back and legs were 7.33 and 7.06 , respectively, before surgery and 3.94 and 4.33 at the end of follow-up, showing improvements of $46.25 \%$ and $38.66 \%$ in the lower back and leg pain scales, respectively. The average ODI score was $57.39 \%$ before surgery and $40.33 \%$ at the end of follow-up, for an improvement of $29.73 \%$.

A statistical analysis was carried out, revealing no significant differences between the groups in relation to the VAS and ODI questionnaires (Figures 1, 2, and 3).

The chi-square or the Fisher's exact test and the Kruskall-Wallis test showed no statistical correlation (with a significance level of 
Table 1. Detailed information for the groups according to postoperative results.

\begin{tabular}{|c|c|c|}
\hline & $\begin{array}{c}\text { Interbody } \\
\text { arthrodesis (cage) }\end{array}$ & $\begin{array}{c}\text { Posterolateral } \\
\text { arthrodesis }\end{array}$ \\
\hline Number of patients & 12 & 18 \\
\hline Sex (Male/Female) & $2 / 10$ & $7 / 11$ \\
\hline Age & 42.67 ( $31-55)$ & $57.44(36-81)$ \\
\hline Surgical time & $275 \min$ & $256 \min$ \\
\hline Blood transfusion per bag & $0.17(0-1)$ & $0.28(0-3)$ \\
\hline \multicolumn{3}{|l|}{ ASA classification } \\
\hline Class I & 6 & 7 \\
\hline Class II & 6 & 10 \\
\hline Class III & 0 & 1 \\
\hline \multicolumn{3}{|l|}{ Number of levels fused } \\
\hline Monosegment & 7 & 12 \\
\hline 2 segments & 5 & 4 \\
\hline 3 segments & 0 & 2 \\
\hline Hospitalization time in days & 3.66 & 4.28 \\
\hline \multicolumn{3}{|l|}{ Complications } \\
\hline Radiculopathy & 1 & 1 \\
\hline Disease in the adjacent level & 0 & 2 \\
\hline Infection & 0 & 2 \\
\hline Failure of synthesis & 1 & 0 \\
\hline Cage migration & 2 & 0 \\
\hline Tobacco user & 4 & 3 \\
\hline Body mass index (BMI) & 27.87 & 26.76 \\
\hline
\end{tabular}

$5 \%$ ) between the rates of arthrodesis and complications for the different techniques (interbody fusion: $X^{2}=0.0893$; posterolateral fusion: $\left.X^{2}=0.7650\right)$

The results from the application of the SF-36 functional scales for its eight domains revealed no statistical significance. (Figures 4 and 5)

The consolidation rate was determined by the author, using simple radiographs in front and profile views. The fusion success rates were similar between the groups with evidence of successful arthrodesis in 11 out of 12 in Group 1 and in 17 out of 18 in Group 2.

When evaluated by fusion grade, Group 1 had 7 patients (58.33\%) in grade $3,4(33.34 \%)$ in grade2, one (8.33\%) in grade 1 , and no

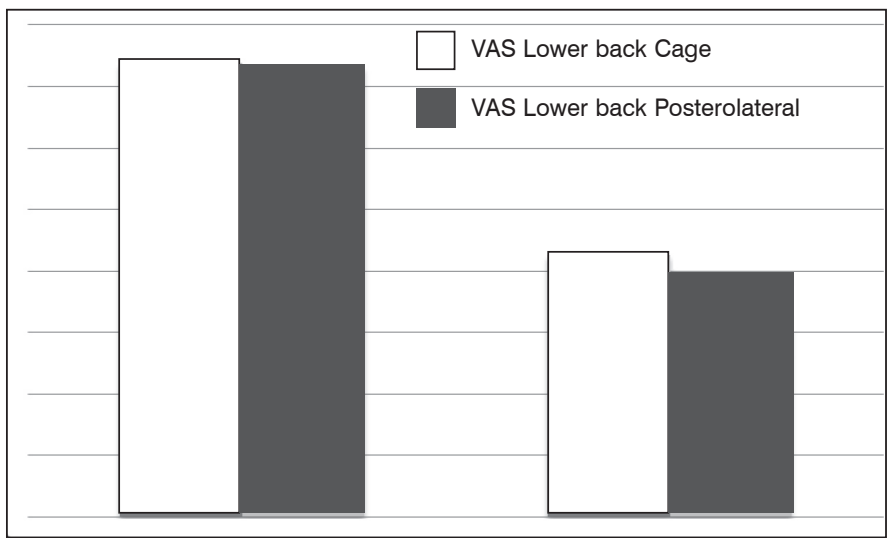

Figure 1. Pre- and Postoperative evolution of Groups $1 \& 2$ as measured by the visual scale for lower back pain (VAS Lower back). patients in grade 0 , thus the fusion was considered successful in 11 (91.67\%) and minimal, though not considered to be a fusion failure, in one (8.33\%) of the patients. In Group 2, 10 patients (55.55\%) were grade 3,7 (38.89\%) grade 2, one $(5.55 \%)$ grade 1 , and once again there were no patients with grade 0 , thus the fusion was considered to be successful in 17 (94.5\%) and minimal, though likewise not considered to be a fusion failure, in one (5.55\%) patient. The need for blood transfusions (in units of packed red blood cells) in Group 1 averaged 0.17 (range 0-1) and in Group 2 averaged 0.28 (range 0-3).

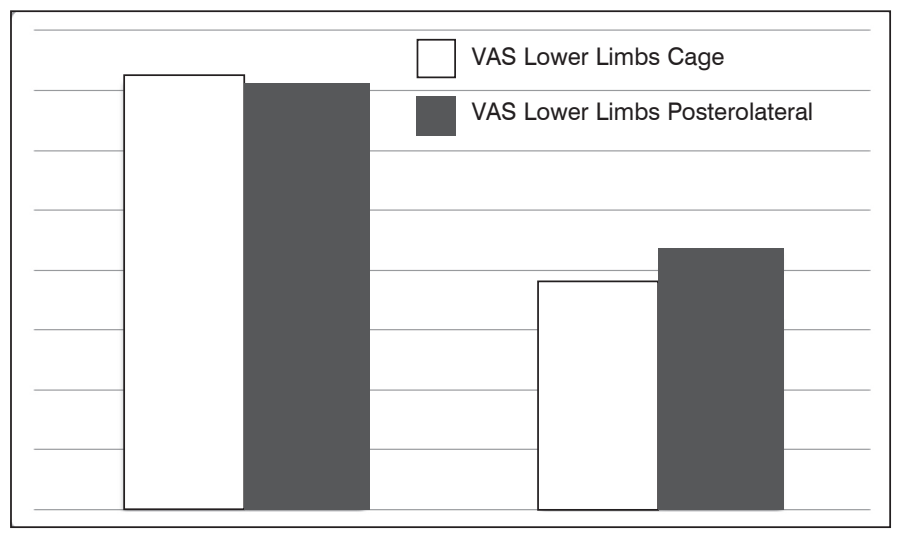

Figure 2. Pre- and postoperative evolution of Groups 1 \& 2 as measured by the visual scale for lower limb pain (VAS Lower Limbs).

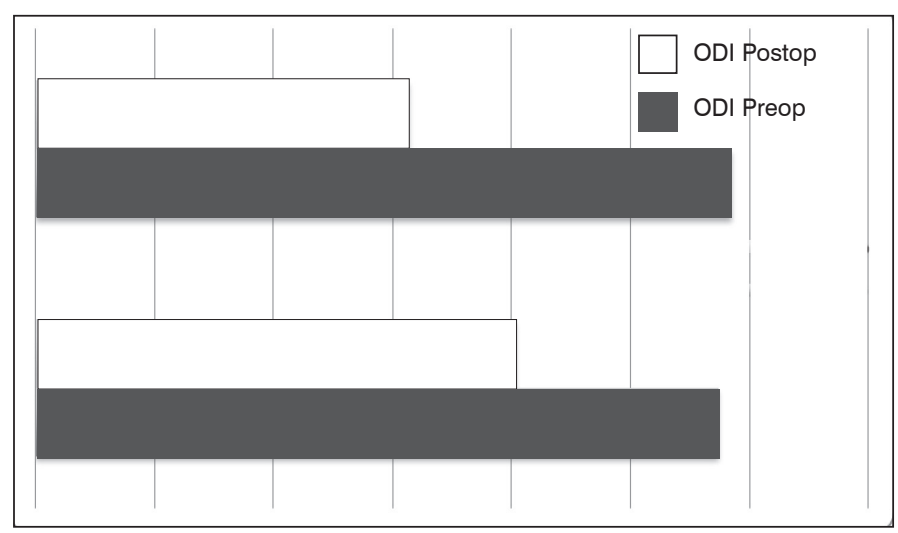

Figure 3. Pre- and postoperative evolution as measured by the Oswestry satisfaction scale (ODI) between Groups 1 and 2 .

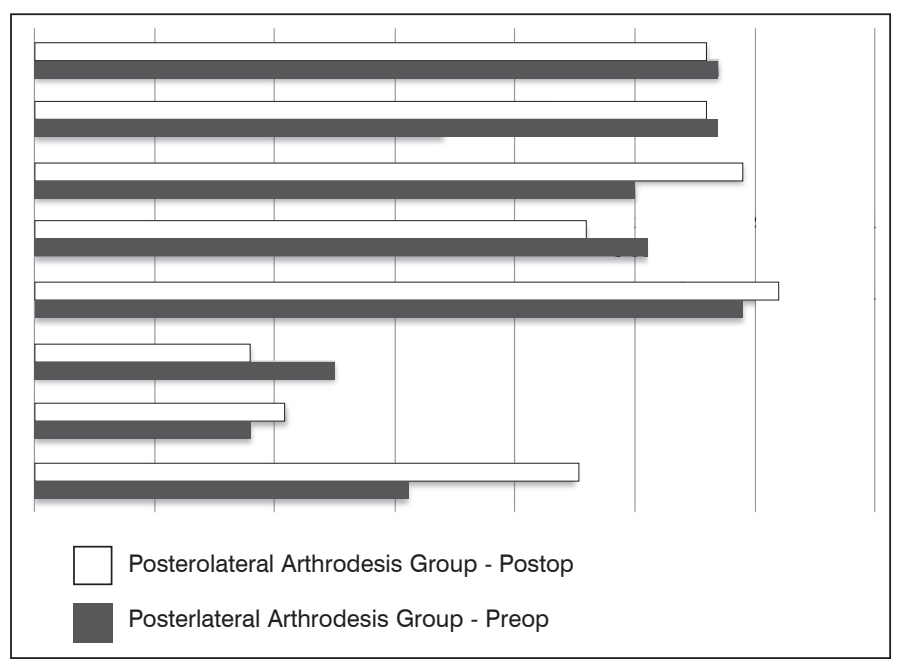

Figure 4. Pre- and postoperative evolution according to the SF-36 questionnaire in the Posterolateral Arthrodesis Group. 


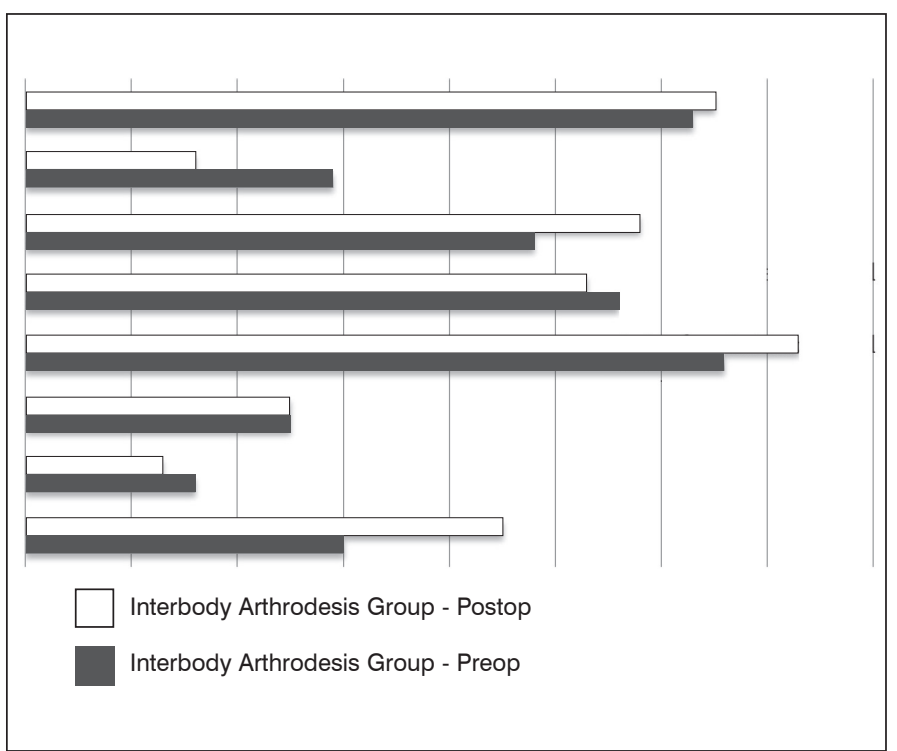

Figure 5. Pre- and postoperative evolution according to the SF-36 questionnaire in the Interbody Arthrodesis Group.

\section{DISCUSSION}

Our study assessed and compared the outcomes of posterolateral and interbody (cage) lumbar arthrodesis, in relation to clinical, radiographical, and functional results in patients with degenerative disease.

Similar or higher scores were observed between the groups for VAS lower back, VAS lower limb, SF-36 functional domain, and Oswestry scores. In both groups there was statistical improvement of the preoperative scores, as previously described in the literature. ${ }^{5}$

In terms of surgery time, the need for transfusion, and days of hospitalization, we observed a possible superiority of posterolateral fusion in relation to interbody fusion. The surgical time in the posterolateral group was 256 minutes versus 275 minutes. No differences were observed in the need for blood transfusions. One patient in the PL group had excessive intraoperative bleeding and required three units of packed red blood cells. This explains the transfusion values $(0.28$ versus 0.17$)$. For the same reason, the hospitalization time was longer (4.28 versus 3.68 days). Additionally, in the PL group we observed older patient ages, a higher percentage of class 1 and class 2 preoperative clinical conditions (ASA), and the need for multi-level approaches in more patients. Both techniques had similar complication rates, with only qualitative differences as shown in Table 1. A prior study ${ }^{10}$ reported that obesity (BMI) influences the outcomes of lumbar fusion and, even though the complication rates were higher in these patients, no differences were noted in relation to clinical or functional results, as was also observed in our sample.

As regards complications, there were no reoperations in Group 1. However, we observed one case of radiculopathy with motor impairment in L4 confirmed by electroneuromyography (the patient refused a new procedure), an assumed synthesis failure which achieved consolidation after six months through the use of an abdominal vest, and two symptomatic cage migrations. In Group 2, new surgeries were required in two cases, one for persistent radiculopathy and the other for deep infection in a patient with rheumatoid arthritis in corticosteroid therapy. Two cases of degenerative disease in the adjacent level showed clinical improvement following conservative treatment.

Comparing reoperation rates between the interbody and posterolateral arthrodesis groups, ${ }^{6}$ we concluded that the rate is higher in the posterolateral group. ${ }^{3}$ The use of an interbody device, while it may reduce the need for further surgery, increases both complication and bleed rates. ${ }^{11}$

Following posterior lumbar arthrodesis, changes or migrations of synthesis in the radiographic images suggesting adjacent degeneration should be correlated and monitored, more for their individual characters than for the fusion in itself. ${ }^{12}$
In addition to the criteria of Linovitz et al., ${ }^{9}$ we used the criteria proposed by Christensen et al. ${ }^{13}$ in a complementary and subjective way, to classify the consolidation rate and the fusion grade. Besides its low cost, non-invasive surgery provides uniformity and high intra- and inter-evaluator reliability (93\% and 86\%, respectively) ${ }^{14}$ when compared to the "gold standard" for checking the fusion mass by surgical exploration.

We believe that two cases of minimal or Linovitz grade 1 fusion and therefore strictly considered failures, one in group 1 and the other in group 2, would better fit within Christensen's concept of doubtful arthrodesis, not really reaching the profile of pseudoarthrosis, given that both are based on anteroposterior radiographs and on the classification of the intertransverse trabecular bone.

Using this method, in Group 1 around 92\% was considered to have achieved complete fusion and $8 \%$ doubtful fusion (there were no cases of pseudoarthrosis). In Group 2, fusion was considered complete in $94 \%$ and doubtful in $6 \%$ (without any cases of pseudoarthrosis). The main reason for doubt about consolidation was the impossibility of adequate visualization of the bed of the arthrodesis due to the presence of the radiopaque metallic rods. (Figure 6)

No correlation was confirmed in our patients between smoking and the multifactorial mechanisms through which nicotine can reduce the rate of fusion and cause central changes in the effects of pain. ${ }^{15,16}$

In terms of limitations of the study, we note the small sample size of the groups, making subgroup analysis in accordance with the different diagnoses impossible. In addition, the minimum time of postoperative follow-up considered for inclusion (six months) may be insufficient for the detection of fusion failures. The groups were not homogenous in terms of age. However, the continued follow-up of these patients and the conducting of future follow-ups could provide these answers at a later date.

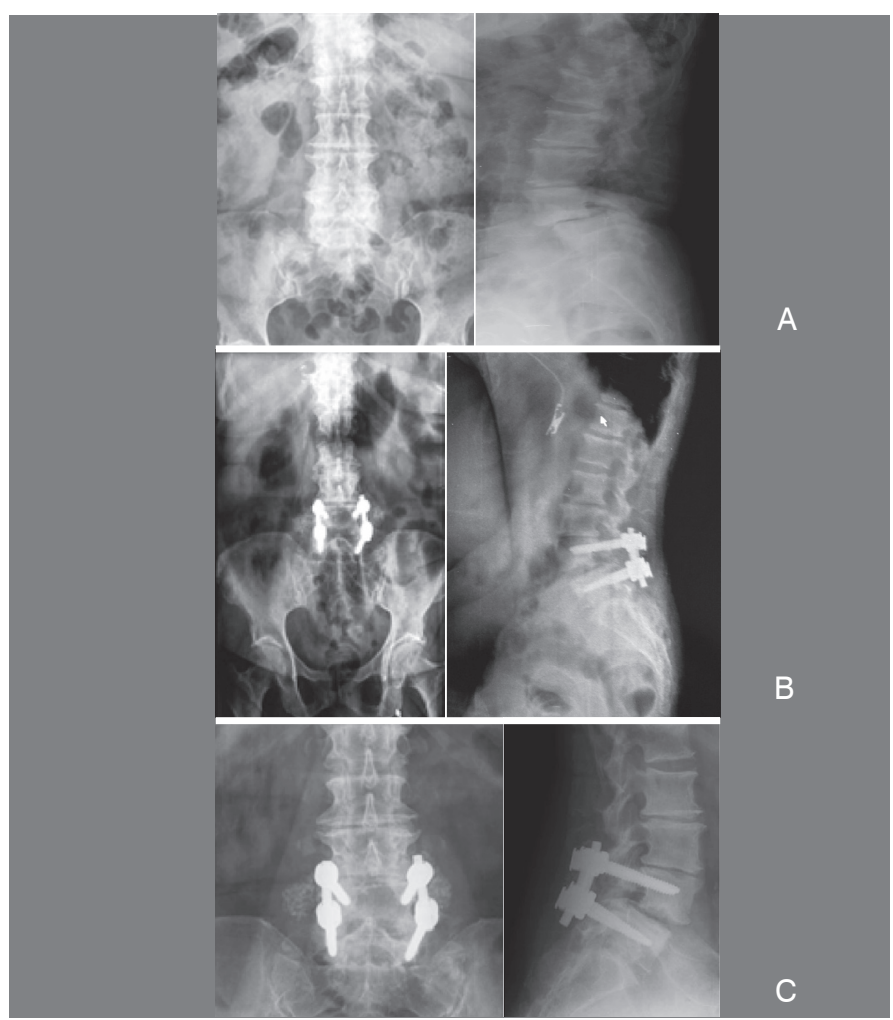

Figure 6. Clinical case of a female patient, 81 years of age, with L4-L5 degenerative spondylolisthesis, who underwent decompression and posterolateral arthrodesis with an autologous graft. (A) Preoperative (B) Immediate postoperative (C) 12 months postoperative, showing Linovitz grade 3 or complete consolidation. 


\section{CONCLUSION}

No clinical or radiographical differences were observed between patients who underwent interbody arthrodesis and those who underwent posterolateral arthrodesis. Both methods resulted in functional and pain-related improvements.

\section{ACKNOWLEDGEMENTS}

The Department of Orthopedics and Traumatology of the Fa- culdade de Ciências Médicas da Santa Casa de São Paulo, to the Head of the Department of Social and Biostatistical Medicine of the Faculdade de Ciências Médicas da Santa Casa de São Paulo Prof. Dr. Paulo Carrara de Castro, to Dr. José Alfredo Corredor Santos, to Dr. Caio Roncon Dias, and to Dr. Rafael Carboni de Souza.

All authors declare no potential conflict of interest concerning this article.

\section{REFERENCES}

1. Cecin AH, Molinar MHC, Borges MA, Morickochi M, Freire M, Bichuetti JAN. Dor lombar e trabalho: um estudo sobre a prevalência de lombalgia e lombociatalgia em diferentes grupos ocupacionais. Rev Bras Reumatol. 1991;31 (1):50-6.

2. Audat Z, Moutasem O, Yousef K, Mohammad B. Comparison of clinical and radiological results of posterolateral fusion, posterior lumbar interbody fusion and transforaminal lumbar interbody fusion techniques in the treatment of degenerative lumbar spine. Singapore Med J. 2012;53(3):183-7.

3. Umeta RS, Avanzi O. Techniques of lumbar-sacral spine fusion in spondylosis: systematic literature review and meta-analysis of randomized clinical trials. Spine J. 2011;11(7):668-76.

4. Lidar Z, Beaumont A, Lifshutz J, Maiman DJ. Clinical and radiological relationship between posterior lumbar interbody fusion and posterolateral lumbar fusion. Surg Neurol. 2005;64(4):303-8.

5. Videbaek TS, Christensen FB, Soegaard R, Hansen ES, Høy K, Helmig P, et al. Circumferential fusion improves outcome in comparison with instrumented posterolateral fusion: long-term results of a randomized clinical trial. Spine (Phila Pa 1976). 2006;31(25):2875-80

6. Han X, ZhuY, Cui C, WuY. A meta-analysis of circumferential fusion versus instrumented posterolateral fusion in the lumbar spine. Spine (Phila Pa 1976). 2009;34(17):E618-25.

7. Daltroy LH, Cats-Baril WL, Katz JN, Fossel AH, Liang MH. The North American spine society lumbar spine outcome assessment Instrument: reliability and validity tests. Spine (Phila Pa 1976). 1996:21(6):741-9.

8. McHorney CA, Ware JE Jr, Lu JF, Sherbourne CD. The MOS 36-item Short-Form Health Survey (SF-36): III. Tests of data quality, scaling assumptions, and reliability across diverse patient groups. Med Care. 1994:32(1):40-66.

9. Linovitz RJ, Pathria M, Bernhardt M, Green D, Law MD, McGuire RA, et al. Combined Magnetic Fields Accelerate and Increase Spine Fusion: A Double-Blind, Randomized, Placebo Controlled Study. Spine. 2002;27(13):1383-8.

10. Djurasovic M, Bratcher KR, Glassman SD, Dimar JR, Carreon LY. The effect of obesity on clinical outcomes after lumbar fusion. Spine (Phila Pa 1976). 2008:33(16):1789-92.

11. Endress S. Instrumented posterolateral fusion - clinical and functional outcome in elderly patients. GMS Ger Med Sci. 2011;9:Doc09. doi: 10.3205/000132.

12. Pellisé $F$, Hernández A, Vidal $X$, Minguell J, Martínez C, Villanueva C. Radiologic assessment of all unfused lumbar segments 7.5 years after instrumented posterior spinal fusion. Spine (Phila Pa 1976). 2007:32(5):574-9

13. Christensen FB, Laursen M, Gelineck J, Eiskjaer SP, Thomsen K, Bünger CE. Interobserver and intraobserver agreement of radiograph interpretation with and without pedicle screw implants: the need for a detailed classification system in posterolateral spinal fusion. Spine (Phila Pa 1976). 2001;26(5):538-43

14. Gotfryd AO, Henriques GG, Poletto PR. Influência da extensão da artrodese lombossacra nos resultados clínicos e funcionais. Coluna/Columna. 2012:11(1):13-6.

15. Glassman SD, Dimar JR 3rd, Burkus K, Hardacker JW, Pryor PW, Boden SD, Carreon LY. The efficacy of rhBMP-2 for posterolateral lumbar fusion in smokers. Spine (Phila Pa 1976). 2007;32(15):1693-8.

16. Cobo Soriano J, Sendino Revuelta M, Fabregate Fuente M, Cimarra Díaz I, Martínez Ureña P, Deglané Meneses R. Predictors of outcome after decompressive lumbar surgery and instrumented posterolateral fusion. Eur Spine J. 2010;19(11):1841-8. 